\title{
A Decision Support System for trade-off analysis and dynamic evaluation of forest ecosystem services
}

\author{
Sandro Sacchelli
}

\section{Introduction}

Starting from the pioneering work of Costanza et al. (1997), several attempts have been made to calculate the monetary value of ecosystem services (ES) and its change over time (Häyhä \& Franzese 2014, Costanza et al. 2014). The quantification and integrated evaluation of these functions are in fact considered a cornerstone for natural resources planning and scenario analysis (Hoogstra-Klein et al. 2017). Among the different techniques for ES evaluation, monetization is the most applied because it can be used for Cost-Benefit Analysis (CBA). In $\mathrm{CBA}$, market and non-market benefits and costs are appraised in economic terms, allowing for comparison of management alternatives by means of either the Net Present Value (NPV) or the capital value (Almansa \& Martìnez-Paz 2011).

The concept of ES evolved with the development of monetary valuation techniques (Plumecocq 2014). In particular, the term was coined as a metaphor to appeal to public opinion (Norgaard 2010) and to best define general concepts such as the "multifunctionality" of environmental goods and

\begin{abstract}
This paper presents an open-source Decision Support System (DSS) able to quantify the economic value of forest ecosystem services and their dynamic trade-offs. Provisioning, regulation and support services, as well as cultural services, can be evaluated by the model. Best management forestry practices can be identified by optimizing specific objective functions, e.g., maximizing the economic value or identifying the ideal rotation period. The model was applied to a silver fir (Abies alba Mill.) stand in central Italy as a case study. Results show the importance of economic parameters (e.g., discount rate) and management practices (e.g., presence/absence of silvicultural thinning) in defining forest values. The main strengths and weaknesses of the DSS are discussed in light of its potential for application in the sector of Payment for Ecosystem Services.
\end{abstract}

Keywords: Ecosystem Services Planning, Complex Systems Analysis, Systemic Rotation Period, Nonlinear Programming services. In TEEB (2010), ES are defined as the direct and indirect contributions of ecosystems to human wellbeing or, in economic terms, the "dividend" that society receives from natural capital. Different methodologies have been applied to determine the relative importance of single ecosystem services or the Total Economic Value (also defined as Total Value of Ecosystem Services - TVES). Estimates vary widely, depending on context (Ninan \& Inoue 2013).

To review the scientific literature on the monetization of ES, De Groot et al. (2012) compiled an Ecosystem Service Value Database (ESVD) containing more than 1350 estimates. Most studies have calculated the economic value of ES using preference methods, such as the Contingent Valuation technique or Choice Experiments (Gürlük 2006, Kumar \& Kumar 2008), or revealed preferences approaches, i.e., the Travel Cost method (Baerenklau et al. 2010, Lankia et al. 2015) or Hedonic Pricing method (Yoo et al. 2014, Czembrowski \& Kronenberg 2016). Benefit Transfer has also been applied extensively (Venn 2005, Sherrouse $\square$ Department of Agricultural, Food and Forest Systems Management, University of Florence, 18, p.le delle Cascine, I-50144, Florence (Italy)

@ Sandro Sacchelli (sandro.sacchelli@unifi.it)

Received: Feb 23, 2017 - Accepted: Nov 23, 2017

Citation: Sacchelli S (2018). A Decision Support System for trade-off analysis and dynamic evaluation of forest ecosystem services. iForest 11: 171-180. - doi: 10.3832/ifor2416-010 [online 2018-02-19]

Communicated by: Luca Salvati
\& Semmens 2014, Richardson et al. 2015). The limitations of these methods have literature (Maguire 2009, Brander \& Koetse 2011, Armbrecht 2014), including suggestions for their improvement. Analyzing the limitations of the above-mentioned methodologies is beyond the scope of this work; for details, see Gsottbauer et al. (2015).

Despite the importance of ES economic quantification, research and empirical examples highlight the main difficulties in monetizing ES. The definition of ES and their classification (such that environmental functions are not accounted for more than once) is a major issue (Kandziora et al. 2013, Mohammed \& Inoue 2017). Another difficulty lies in quantifying the TVES. The TVES is often calculated as the simple sum of ES values (D'Amato et al. 2016), without taking into consideration neither the analysis of trade-offs nor the competitive and complementary nature of ES (Ninan \& Inoue 2013).

In the case of forest ES, calculating the TVES is of great importance in forest governance (Secco et al. 2017). Unfortunately, it is often calculated in static terms, ignoring the dynamic nature of stands and the possible impact of disservices and disturbances on ES (e.g., damage to wildlife and storms). A number of studies have focused on the dynamic analysis of forest ES and on determining their economic value. Häyhä et al. (2015) used a Geographic Information System (GIS) to evaluate trade-offs among different ES, whereas Rose \& Chapman (2003) provided additional insights into ES estimation. The latter have implemented a method to define the optimal stand age for maximizing the Net Present Value (NPV) of multiple ES. Trade-off evaluation among been illustrated and amply discussed in the 
forest ES is influenced by the spatial-temporal scale of analysis (Wang \& Fu 2013). A DSS should facilitate multiscale approaches (in particular from the spatial point of view) so that the effects of forest manage ment (e.g., from good production to landscape improvement) can be taken into account. The literature mainly focuses on large/medium-scale assessment of ES trade-offs. For example, Mazzaro De Freitas et al. (2017) evaluated the different offsetting implementation practices and their effects on nature conservation and socioeconomic development in Brazil. Bottalico et al. (2016) used an integrated GIS-based approach for scenario analysis and economic valuation of wood production and carbon sequestration trade-offs in forests of the Molise region (Italy).

Two main economic biases are present in the literature on ES monetization. First, several works are based on the assumption of Turner et al. (2003) that the marginal value of ES is relevant for economic quantification. Indeed, marginal values can provide a good approximation of ES variations. However, in the case of market exchanges and trade between buyers and sellers, the total value of ES must be taken into account. For example, when a forest compartment is sold, the total value should be considered and not just the variations in the flux of ES or in marginal utility. The second bias stems from the use of NPV in economic analysis, a method widely applied in environmental economics, as the NPV is calculated for a limited period of investment. However, the effects of forest assessment and management are not limited to just one rotation period. This is demonstrated by the fact that forest economics and appraisal historically take into account the Faustmann's Rule for forest estimation (Faustmann 1849). Faustmann's formula quantify the present value of bare land for a specific forest. This value derives from the capitalization of periodic forest income obtainable in a rotation period. Faustmann noted that the marginal costs of delaying harvests include both foregone interest payments and the loss of value due to delayed rotation (Brazee 2001). This means that the economic value of forest ES should be quantified as capitalized value and not as NPV.

Furthermore, there is a gap between existing Decision Support Systems (DSS) for management/monetary evaluation of forests and the requirements of end-users (Wright et al. 2011). Bagstad et al. (2013) completed a detailed literature review of existing DSS for assessing, quantifying, modeling, valuing and/or mapping ES. The study describes 17 ES tools and assesses their "readiness" for application in the decision-making processes. One specific assessment looks at the ability to monetize ES.

To overcome the above-mentioned limitations, an open-source DSS was developed which could be applied in: (i) the analysis of forest ES trade-offs; and (ii) the optimization of forest management in order to maximize the economic value of ES. The proposed model quantifies the trade-offs among ES for different economic and management variables. So far, the few studies on this topic in the literature have usually analyzed no more than two ES each. An additional strength of the proposed model is its optimization of ES values through a nonlinear programming procedure. Specific objective functions such as maximization of the monetary or biophysical value of ES can be defined by modifying specific input data and parameters.

\section{Methodology}

The DSS evaluation criteria are those suggested by Bagstad et al. (2013). The model was developed in spreadsheet form and consists of three sections: input, processing and output.

\section{Model approach and data input}

Basic information on forest stand characteristics and ES categories is provided in the input page. The rotation period is set to a preliminary value. There are two possible management options (high forest and coppice) with different potential yields in the final cut $(0-100 \%$, e.g., to consider release of standards in coppices). Thinning intervention and the age of thinning are additional options. Site parameters are slope, distance from roads and soil fertility. Dynamic assessment of forest characteristics is used to determine trade-offs among ES. In this respect, additional input can be provided by yield tables for evenaged stands, or norms for uneven-aged forests. Yield tables are applied to establish polynomial functions suitable for calculating the total volume and mean diameter. These variables are differentiated according to the presence or absence of thinning. TOOFES applies the commonly used TEEB (2010) classification of ES, which considers four different groups: (i) provisioning; (ii) regulating; (iii) habitat or supporting; and (iv) cultural services. Each category com- prises a series of specific subcategories (TEEB 2010) such as (i) provisioning services: food, fresh water, raw materials, medicinal resources; (ii) regulating services: local climate and air quality regulation, carbon sequestration and storage, moderation of extreme events, waste-water treatment, erosion prevention and maintenance of soil fertility, pollination, biological control; (iii) habitat or supporting services: habitats for species, maintenance of genetic diversity; (iv) cultural services: recreation and mental and physical health, tourism, aesthetic appreciation and inspiration, spiritual experience and sense of place. Although only one category per class was considered in testing the model, the structure of the DSS can easily be updated with additional ES functions.

Provisioning services are here connected to raw materials production. In short, the discount rate and one to three wood categories (differentiated by diameter) can be input. A selling price can be defined (assuming sale at the landing site) for each category. Production costs take into account productivity and the unitary costs of labor and machinery for felling trees and extracting wood, as well as general expenses (direction costs, administrative costs and interest on advanced capital).

Regulating services focus on carbon sequestration. Calculations are based on the annual increment, taking into account carbon accumulated in biomass above and below ground. The annual contribution of other carbon pools such as litter, deadwood and organic soil is considered negligible, because variations in carbon content are detected in the very long term (Häyhä et al. 2015). The variables used for quantification of stored carbon are the volume of growing stock, the Biomass Expansion Factor (BEF), Wood Basic Density (WBD) and the root/shoot ratio ( $R$ - Federici et al. 2008). The financial parameter is the price of carbon.

The value of supporting services focuses on the analysis of biodiversity in the examined forests. Pearce \& Moran (1994) define

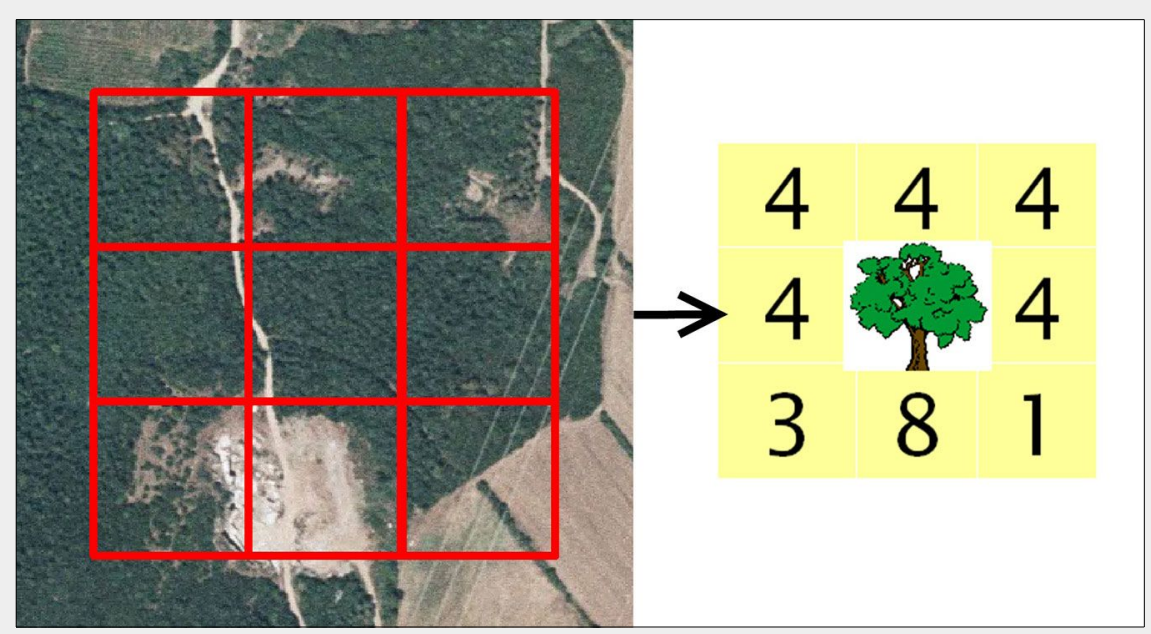

Fig. 1 - Example of pattern analysis for the studied forest (central cell). 
biodiversity as genetic, species and ecosystem diversity. The literature contains several examples of forest biodiversity analyses for each of these categories (see Bartkowski et al. 2015 for a literature review). It is harder to complete a dynamic analysis of this component in one or more forest life cycles (Uggla et al. 2016). Moreover, flexible DSS able to quantify the economic variability of biodiversity are not present in the literature. To overcome these difficulties, a method based on ecosystem diversity was adopted in TOOFES. Ecosystem diversity is an easier parameter to compute in respect of genetic and species diversity. Ecosystem diversity can be calculated in relation to land use modification and, as a consequence, to pattern analysis (Kallio et al. 2008). It is usually evaluated using Geographic Information System (GIS) because such platforms can be used to automatically quantify several diversity indexes. In order to execute all operations in a single model, TOOFES applies a spreadsheet, cellbased procedure for pattern analysis. An example of input data for ecosystem diversity analysis is represented in Fig. 1. A $3 \times 3$ kernel shows land use for the eight cells around the analyzed forest. Land categories are: (1) agricultural area; (2) young coppice ( $<5$ years old); (3) intermediate coppices (5-20 years old); (4): mature coppices ( $>20$ years old); (5) young high forests (<10 years old); (6) intermediate high forest (10-50 years old); (7) mature high forests (>50 years old); (8) artificial surfaces, bare rocks, glaciers and perpetual snow, wetlands, water bodies. Each of the above classes have a different visual impact and habitat suitability. Classification can be completed through either photointerpretation or field evaluation. Patterns in raster images are necessarily simplified with respect to real ones (Fig. 1).

An additional factor that must be taken into account is the economic value of biodiversity $\left(\operatorname{biod}_{\tau}\right)$ as derived from a Benefit Transfer approach or from ad hoc studies.

Cultural service is based on monetary quantification of touristic and recreational value. This value is often calculated in static terms. For example, the value of a forest at year $x$ (commonly calculated through Choice Experiment, Contingent Valuation or Travel Cost methods) is not necessary the same for different forest ages.

The perceived touristic and recreational value of an environment does not seem to be a permanent construct but must be seen in the context of experiences and goods/service variations over time. It depends on personal experience and emotions (Kortsch et al. 2015). Quantification of these values should therefore take into account the entire life cycle of a forest or comparison among forests of different ages. To address this issue a method that correlates a dendrometric parameter with the cultural value is proposed. Ribe (2009) confirmed the hypothesis that if other forest stand and facility characteristics do not vary, there is a direct proportion between dendrometric variables (in particular mean tree diameter) and touristic-recreational value. The inputs for calculating cultural significance are therefore: (i) the monetary value of touristic-recreational utility, as determined using a Benefit Transfer approach or from ad hoc research; and (ii) the age of the forest at the time of data collection.

\section{Processing}

The "Processing" section represents the core of the DSS. Dendrometric variables can be calculated using polynomial functions derived from yield tables. The volume of a forest $\left(\mathrm{m}^{3} \mathrm{ha} \mathrm{a}^{-1}\right)$ at a given year is determined as follows (eqn. 1):

$$
v_{x}=a x^{2}+b x^{2}+c x
$$

where $a, b$ and $c$ are the estimated coefficients and $x$ is the age of the forest.

Based on a similar approach, the mean diameter of a stand is calculated as (eqn. 2):

$$
\Phi_{x}=d x^{3}+e x^{2}+f x
$$

where $\Phi_{\mathrm{x}}$ is the mean diameter $(\mathrm{cm})$ at year $x$, and $d, e$ and $f$ are the estimated coefficients.

The market value of raw material is calculated as stumpage value for both final felling and thinning. It depends on the possible assortment types, their prices and production costs. Stumpage value is quantified following the methodology presented by Sacchelli et al. (2013). The revenues $\rho$ obtained from the stand at year $x$ are calculated as (eqn. 3):

$$
\rho_{x}=\sum v_{i, x} p_{i} \lambda_{v, x}
$$

where $i$ is the number of wood assortments, $p_{i}$ the average market price of the $i$ th assortment $\left(\epsilon \mathrm{m}^{-3}\right)$ and $\lambda$ the percentage of extracted volume for silvicultural treatment $v$ at year $x$.

For the $\alpha$-th phase of the production process, the costs $K$ at age $x$ are calculated as (eqn. 4):

$$
K_{\alpha, x}=\frac{k_{\alpha}}{\eta_{\alpha}} v_{x}
$$

where $k_{a}$ is the hourly cost for the $\alpha$-th process phase $\left(\epsilon \mathrm{h}^{-1}\right)$ and $\eta_{\alpha}$ is the hourly productivity for the $\alpha$-th process phase $\left(\mathrm{m}^{3}\right.$ $\left.h^{-1}\right)$.

The hourly cost includes machinery and labor ( $3^{\text {rd }}$ and $5^{\text {th }}$ level) costs. For each phase the DSS defines the organization of the production process and calculates hourly productivity based on a prescribed yield, slope, and tree characteristics (volume and diameter), as well as the extraction distance. The direction cost $D_{x}$, administrative expense $A d_{\mathrm{x}}$ and interest $I_{\mathrm{x}}$ are also calculated to determine the total cost (Sacchelli et al. 2013).

Lastly, the value of provisioning services (VPS) is determined using the Faustmann's formula (Faustmann 1849):

$$
\begin{aligned}
& V P S=\left\{\sum _ { x = 0 } ^ { \omega } \left[\left(\rho_{x}+w_{x}-\sum_{\alpha} K_{\alpha, x}-D_{x}-A d_{x}\right.\right.\right. \\
& \left.\left.-I_{x}-S_{x}-z_{x}\right) \cdot(1+r)^{(\omega-x)}\right] \text {. } \\
& \left.\cdot\left[(1+r)^{\omega}-1\right]^{-1}\right\} \cdot s
\end{aligned}
$$

where $\omega$ is the rotation period of the forest (year), $r$ is the discount rate, $w$ the annual revenue ( $€$ ha $^{-1}$ year $\left.^{-1}\right), S$ the renovation cost $\left(€\right.$ ha $\left.^{-1}\right), z$ the annual cost $\left(€\right.$ ha $^{-1}$ year $\left.{ }^{-1}\right)$ and $s$ the forest area (ha).

The value of regulating services (VRS) due to carbon sequestration is defined as the capitalized value of carbon stored yearly in above- and below-ground biomass. The amount of carbon sequestered in trees is calculated through the procedure proposed by Federici et al. (2008). The authors quantify total carbon tons at year $x$ in above-ground $\left(C_{A G, x}\right)$ and below-ground $\left(C_{B C, x}\right)$ dry biomass using the following equations (eqn. 6 , eqn. 7 ):

$$
\begin{aligned}
& C_{A G, x}=\left(v_{x}-v_{x-1}\right) \cdot B E F \cdot W B D \\
& C_{B G, x}=\left(v_{x}-v_{x-1}\right) \cdot W B D \cdot R
\end{aligned}
$$

where $v_{x}-v_{x-1}$ represents the annual volume increment at year $x\left(\mathrm{~m}^{3} \mathrm{ha}^{-1}\right.$ year $\left.{ }^{-1}\right)$. VRS is therefore (eqn. 8):

$$
V R S=\frac{\sum_{x=0}^{\omega}\left[\left(C_{A G, x}+C_{B G, x}\right) \cdot \psi \cdot \sigma \cdot(1+r)^{(\omega-x)}\right]}{(1+r)^{\omega}-1} \cdot s
$$

where $\psi$ is the biomass/carbon conversion factor ( $t / t$ of dry matter) and $\sigma$ the carbon price $\left(\epsilon \mathrm{t}^{-1}\right)$ reported in the database of the Euro-Mediterranean Centre on Climate Change (CMCC 2014).

Biodiversity is determined by pattern analysis based on relative richness (Turner 1989). Taking into account the square matrix presented above, diversity in the examined forest at year $x\left(\alpha_{x}\right)$ is calculated as follows (eqn. 9):

$$
\chi_{x}=\frac{n_{x}}{M A X n} \cdot 100
$$

where $n_{x}$ is the number of different classes present in the kernel at year $x$, and MAXn is the maximum possible number of classes in the entire matrix.

Land use in the eight cells around the studied forest (see Fig. 1) can remain constant (in the case of categories 1 and 8) or have a dynamic trend. In other words, coppices can shift from class 2 to 3, 3 to 4 and 4 to 2 , and high forests can change from class 5 to 6,6 to 7 and 7 to 5 . For these management typologies, a fixed rotation length is hypothesized ( 25 years for coppices and 100 years for high forests).

The yearly monetary value of biodiversity $\left(\operatorname{biod}_{x}\right)$ is then calculated by normalizing the available economic value $\left(\operatorname{biod}_{\tau}\right)$ over the maximum biodiversity index reported for the entire rotation period $\left(M A X_{x \omega}\right.$ in eqn. 10). This hypothesis is acceptable because biodiversity is often calculated with reference to the maximum potential of a particular area (e.g., by applying stated 


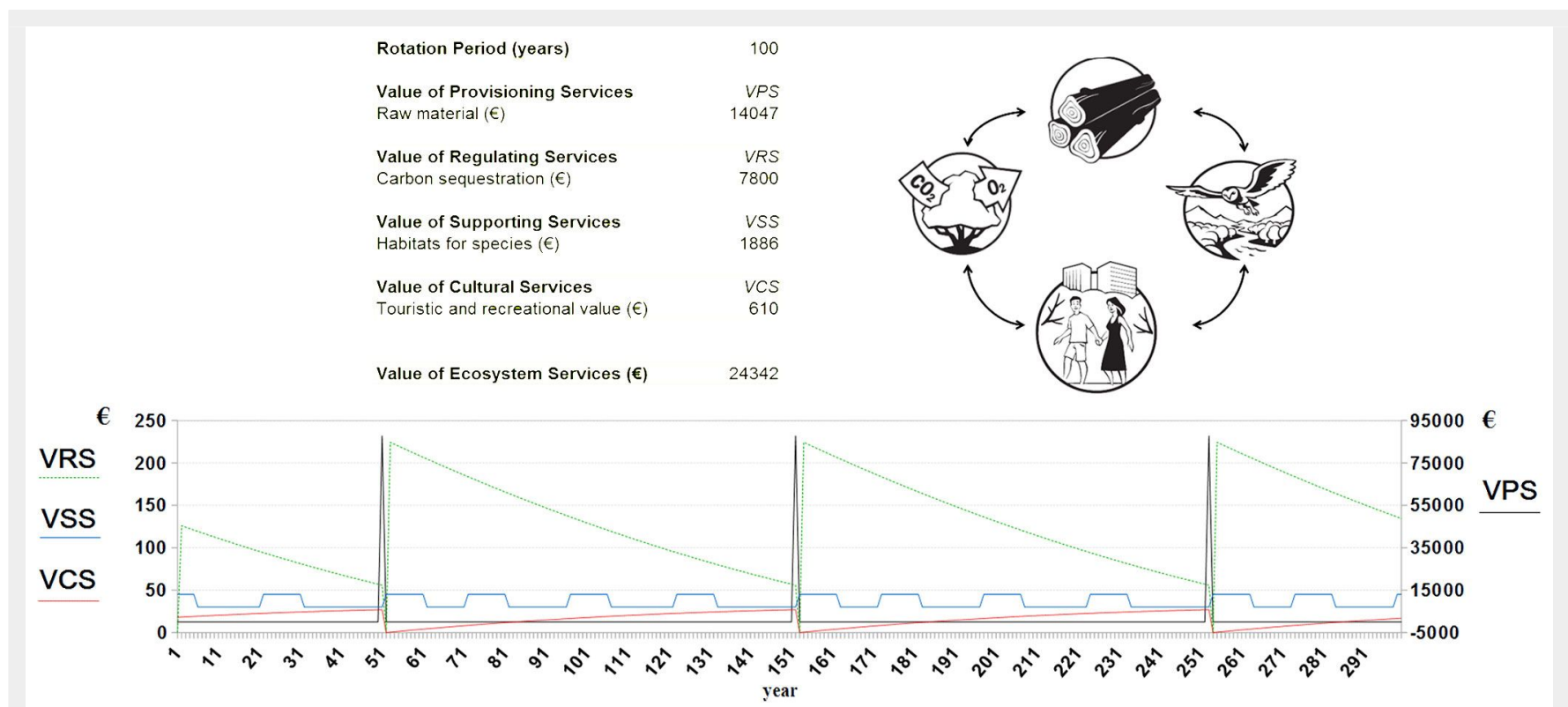

Fig. 2 - Example of a generic output from the TOOFES model (source of icons: TEEB 2010).

preference methods to mature stands eqn. 10).

$$
\operatorname{biod}_{x}=\frac{\chi_{x}}{M A X_{\chi_{\omega}}} \cdot \operatorname{biod}_{\tau}
$$

The value of supporting services (VSS) is therefore (eqn. 11):

$$
V S S=\frac{\sum_{x=0}^{\omega}\left[\operatorname{biod}_{x}(1+r)^{(\omega-x)}\right]}{(1+r)^{\omega}} \cdot S
$$

The annual value of touristic and recreational function at year $x\left(\operatorname{tr}_{x}\right)$ is dependent on stand characteristics and in particular on diameter (eqn. 12):

$$
t r_{x}=\frac{\psi_{x}}{\psi_{\gamma}} \cdot r_{\gamma}
$$

where $\operatorname{tr}_{\gamma}$ is the economic value of the touristic and recreational function at year $\gamma$ and $\Phi_{\gamma}$ is the mean forest diameter at year $\gamma$ (calculated using eqn. 2).

The value of cultural services (VCS) is therefore (eqn. 13):

$$
V C S=\frac{\sum_{x=0}^{\omega}\left[\operatorname{tr}_{x} \cdot(1+r)^{(\omega-x)}\right]}{(1+r)^{\omega}}
$$

Lastly, the value of ES (VES) can be calculated as the sum of each function's value in consideration of their dynamic trend (eqn. 14):

$$
V E S=V P S+V R S+V S S+V C S
$$

In the present work, the term VES is applied instead of "TVES" because only one ecosystem service is estimated per category.

\section{Output}

A sample TOOFES output is reported in Fig. 2, which shows the value of each function as well as the VES. A graphical visualization of yearly monetary significance for each ecosystem service is also included. Additional data can be added to the sheet through a link with the Processing page.

\section{Optimization}

Dynamic assessment of forest ES is an issue in complex systems analysis. In this sense the ability to assess ES trade-offs using TOOFES is of great interest for forest managers and stakeholders. The addition of optimization techniques for nonlinear systems would further improve DSS. To address this point, TOOFES was implemented in an Apache OpenOffice Calc spreadsheet. Calc can be equipped with the NLPSolver (Solver for Nonlinear Programming - Xie 2009), an extension with a user-friendly graphical interface and containing algorithms to solve nonlinear problems. In the present application, the Differential Evolution Particle Swarm (DEPS) evolutionary algorithm was applied because of its stability, good performance and various applications in nonlinear analysis (Sacchelli \& Fabbrizzi 2015).

Optimization can be applied using different objective functions. This work focused on determining the best rotation period for maximizing the value of each ecosystem service; the VES was calculated in accordance with the following equation (eqn. 15):

$$
\operatorname{MAX}\left(V^{*}\right) \forall \omega \in N, \omega \in \Omega
$$

where $V^{*}$ is the value of provisioning or regulating or supporting or cultural or ecosystem services, $N$ is the sample of natural numbers and $\Omega$ is the rotation period allowed by local norms and policies.

\section{Case study}

The TOOFES model was tested on an area located in the Foreste Casentinesi, Monte Falterona and Campigna National Park (Tus- cany, Italy). The national park covers more than 36,000 ha in a mountainous region of the Apennines between Emilia-Romagna and Tuscany. Forests are extended over about $83 \%$ of the area and are mainly dominated by hornbeams, turkey oaks, sessile oaks and chestnut woods. Conifer stands (e.g., silver fir Abies alba Mill.) and artificial black pine forests also cover a significant area. The test area was located in the heart of the National Park close $(1.1 \mathrm{~km})$ to the Holy Hermitage of Camaldoli, a monastery founded in 1012 (Fig. 3). The forest is characterized by a 1-ha silver fir compartment. The study area was chosen for its representativeness at wider spatial scales, both regional and national. Silver fir forests in Italy are mainly artificial stands in the mountainous areas of the Apennines and Alps as well as on public property (73\%), as in the case of the examined parcel. The input data for the case study are reported in Tab. 1.

\section{Results and discussion}

The first parameters analyzed were the different ES values for the stand (VPS, VRS, VSS, VCS, VES). The evaluation relates the above output to different factors, i.e., silvicultural parameters (rotation period, presence/absence of thinning) and an economic parameter (discount rate - Fig. 4).

The increase in discount rate from $2 \%$ to $4 \%$ obviously led to poorer economic results for all $V^{*}$ typologies: $89 \%$ for VPS, $40 \%$ for VRS, $40 \%$ for VSS and $64 \%$ for VCS, with an average $57 \%$ decrease overall.

Sensitivity analyses based on rotation length show different trends for each ecosystem service. In general, for low discount rates $(2 \%)$ the VPS peaks at around 90 years, and then decreases progressively. If the discount rate is increased to $4 \%$, a shorter rotation appears to be the best option for improving the VPS. The 
Tab. 1 - Model input data for the case study area.

\begin{tabular}{|c|c|c|c|}
\hline Data & U.M. or code & Value & Source and/or notes \\
\hline Age & years & 50 & Regional Forest Inventory and field survey \\
\hline Surface & ha & 1 & Photointerpretation and field survey \\
\hline Rotation period & years & Sensitivity analysis & - \\
\hline Management & $\begin{array}{l}\text { (1):high forest } \\
\text { (2):coppice }\end{array}$ & 1 & $\begin{array}{l}\text { Final felling: clear cut in accordance with Tuscany Region } \\
\text { Forestry Law (Tuscany Region 2003) }\end{array}$ \\
\hline Thinning & $\begin{array}{l}\text { (1): presence } \\
(0): \text { absence }\end{array}$ & Sensitivity analysis & 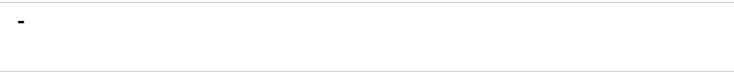 \\
\hline Age of thinning & year & 30 & ISAFA (1970); $26 \%$ of biomass removal was considered \\
\hline Slope & $\%$ & 33 & Regional Forest Inventory \\
\hline Distance from roads & $\mathrm{m}$ & 808 & Regional Forest Inventory \\
\hline Fertility & $\begin{array}{l}\text { (1): very low; } \\
\text { (2): low; } \\
\text { (3): medium; } \\
\text { (4): high; } \\
\text { (5): very high }\end{array}$ & 5 & Regional Forest Inventory \\
\hline Volume & $\mathrm{m}^{3} \mathrm{ha}^{-1}$ & $\begin{array}{l}\text { Related to age } \\
\text { and yield table }\end{array}$ & ISAFA (1970) \\
\hline Diameter & $\mathrm{cm}$ & $\begin{array}{l}\text { Related to age } \\
\text { and yield table }\end{array}$ & ISAFA (1970) \\
\hline Discount rate & $\%$ & Sensitivity analysis & - \\
\hline Class of assortments & $\begin{array}{l}\text { (a): first class } \\
\text { (b): second class } \\
\text { (c): third class }\end{array}$ & $\begin{array}{l}\text { Diameter: } \\
\text { (a): }<20 \mathrm{~cm} \\
\text { (b): } 20 \div 40 \mathrm{~cm} \\
\text { (c): }>40 \mathrm{~cm}\end{array}$ & $\begin{array}{l}\text { Technical literature } \\
\text { (http://www.rivistasherwood.it/tecniko-e-pratiko.html); } \\
\text { survey by local experts }\end{array}$ \\
\hline $\begin{array}{l}\text { Price for each class of } \\
\text { assortment }\end{array}$ & $€ \mathrm{~m}^{-3}$ & $\begin{array}{l}\text { (a): } 25 \\
\text { (b): } 48 \\
\text { (c): } 73\end{array}$ & $\begin{array}{l}\text { Technical literature } \\
\text { (http://www.rivistasherwood.it/tecniko-e-pratiko.html); } \\
\text { survey by local experts }\end{array}$ \\
\hline Production costs & $€ \mathrm{~m}^{-3}$ & $\begin{array}{l}\text { Calculated following } \\
\text { Sacchelli et al. (2013) }\end{array}$ & $\begin{array}{l}\text { Dendrometric parameters were processed using TOOFES. } \\
\text { No renovation costs are included (natural renovation is } \\
\text { hypothesized - Tuscany Region 2003) }\end{array}$ \\
\hline Biomass Expansion Factor & - & 1.34 & Federici et al. (2008) \\
\hline Wood Basic Density & Dry weight tons $\mathrm{m}^{-3}$ & 0.38 & Federici et al. (2008) \\
\hline Root/shoot ratio & - & 0.28 & Federici et al. (2008) \\
\hline Carbon price & $€ \mathrm{t}^{-1}$ & 7 & CMCC (2014) \\
\hline Biodiversity value & $€$ ha $^{-1}$ year $^{-1}$ & 45 & $\begin{array}{l}\text { Ten Brink et al. (2000). WTP per person per year for } \\
\text { woodland was calibrated on Tuscany residents }\end{array}$ \\
\hline Land use at year 0 & $\begin{array}{l}\text { See chapter } \\
\text { "Model approach" }\end{array}$ & $\begin{array}{l}775 \\
7 \times 7 \\
766\end{array}$ & Photointerpretation and field survey \\
\hline Touristic recreational value & $€$ ha $^{-1}$ year $^{-1}$ & 27 & Riccioli et al. (2012) \\
\hline $\begin{array}{l}\text { Selected age for analysis of } \\
\text { touristic recreational value }\end{array}$ & years & 100 & $\begin{array}{l}\text { The age was set at } 100 \text { years, as suggested in Rose \& } \\
\text { Chapman (2003) }\end{array}$ \\
\hline
\end{tabular}

characteristics of the study area confirm past experience in conifer stands of the Italian Apennines and Italy in general, where thinning often leads to negative stumpage values. In this case the stumpage value after thinning is lesser than zero and, as expected, the capitalized VPS with thinning is lower than the VPS without thinning. Due to the greater increase in annual volume for the early stand ages, the VRS tends to decrease as the rotation period increases. The VCS shows an opposite trend. This value is strictly related to certain tree dimensions (in particular the mean diameter). Higher rotation lengths lead to an increase in the economic value of cultural services. Thinning seems to be the best practice for improving the VCS. Thinning increases the VCS by about 3\%, supporting assertions by Ribe (2009) and Lupp et al. (2013). Ribe (2009) related the visual importance of forests to diameter, while Lupp et al. (2013) suggest that although thinning has a positive effect on

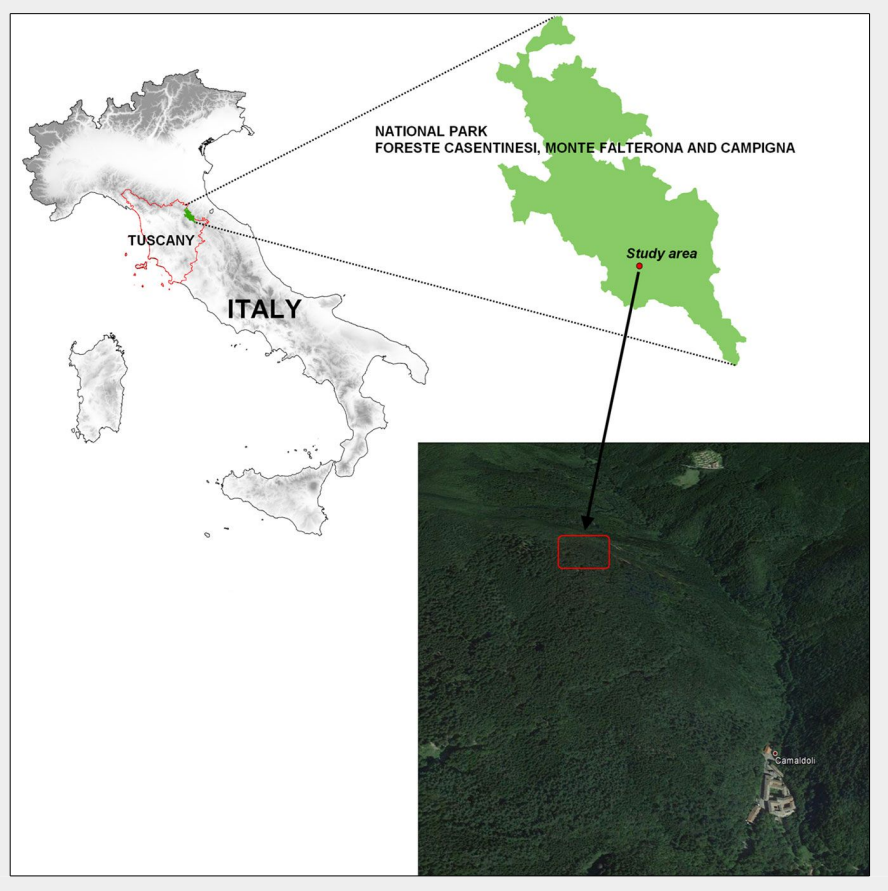

Fig. 3 - Location of the study area $\left(43^{\circ}\right.$ $47^{\prime} 58.39^{\prime \prime} \mathrm{N}, 11^{\circ}$ $\left.48^{\prime} 47.57^{\prime \prime} \mathrm{E}\right)$. Source: Google Earth ${ }^{\oplus}$. Image: August 29, 2014. Last accessed: January $23,2017$. 

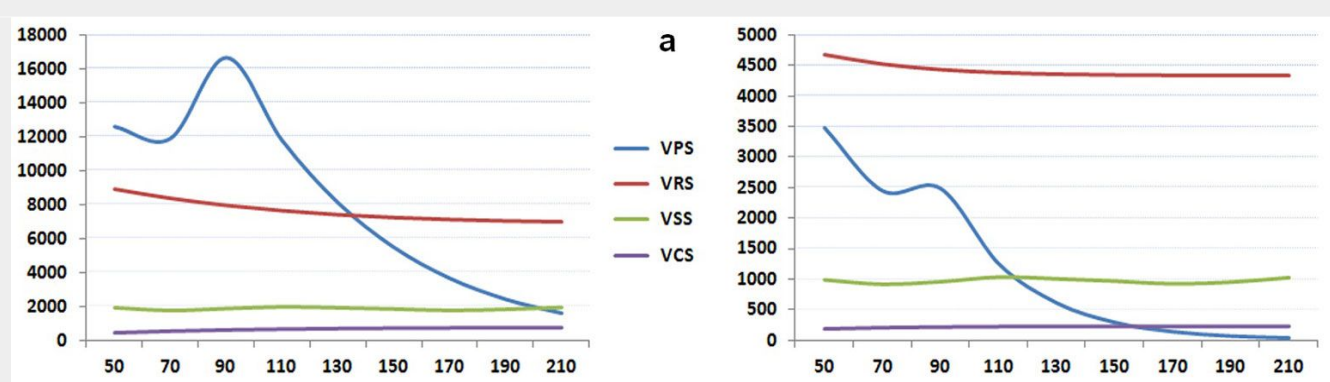

b Fig. 4 - Variation in economic value $(\epsilon$, $y$ axis) with respect to — vps rotation period — vRs (years, in x-axis), thin— vss ning intervention and — vcs discount rate.

(a): absence of thinning, $2 \%$ discount rate; (b): absence of thinning, $4 \%$ discount
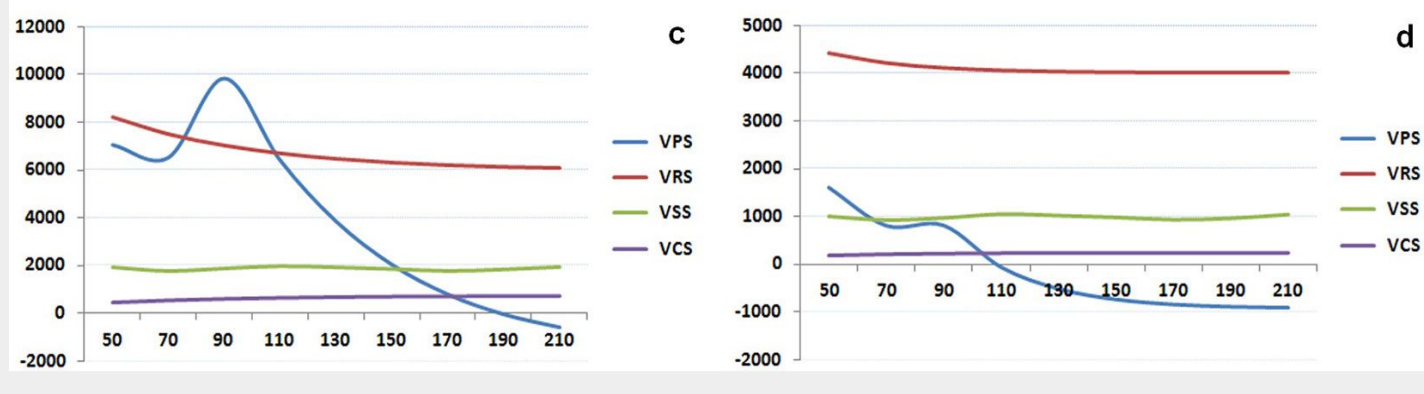

d rate; (c): thinning at year $30,2 \%$ discount rate; $(d)$ : thinning at rate; (d): thinning at rate. visual impact, this effect is very subtle in conifer stands.

VSS trends fluctuate instead; the value depends on the relative complexity of examined patterns and is based on land use as well as the age of close stands. It ranges from a minimum of $923 €$ to a maximum of $1949 €$ in the considered rotation period (50-210 years).

Among total values, the VPS appears to be the one that fluctuates the most with rotation length and discount rate (values from $-904 €$ to $16,643 €$ ). For low discount rates and shorter rotation ages, it is the most important component of the VES. Should the above parameters increase, it could also reaches negative values (Fig. 4C, Fig. 4d). The VRS is also somewhat important, with values ranging from 4,017 to $8,940 €$. Lastly, VCS can vary from a minimum of 178 to a maximum of $739 €$.

The VES ranges from 4,332 to $27,049 €$ (Fig. 5). The main factor affecting the VES is the discount rate, with an average $62 \%$ recorded decrease when the discount rate increases from $2 \%$ to $4 \%$. Taking into ac- count forest treatment, the presence of thinning reduces the VES by about $26 \%$.

Another issue that can be investigated by TOOFES is the optimal rotation length to maximize the value of each forest function or, in other words:

- the provisioning services rotation period (PSRP): the rotation period for maximizing the VPS;

- regulating services rotation period (RSRP): the rotation period for maximizing the VRS;

- supporting services rotation period (SSRP): the rotation period for maximizing the VSS;

- cultural services rotation period (CSRP): the rotation period for maximizing the VCS;

- systemic rotation period (SRP): the rotation period for maximizing the VES.

Optimal ages are reported in Tab. 2, differentiated for ES, presence/absence of thinning, as well as discount rate (1-5\%). The admissible rotation period $\Omega$ is set to 50-300 years. Tuscany Region Forestry Law (LR 48/2003) defines 70 years as the mini-

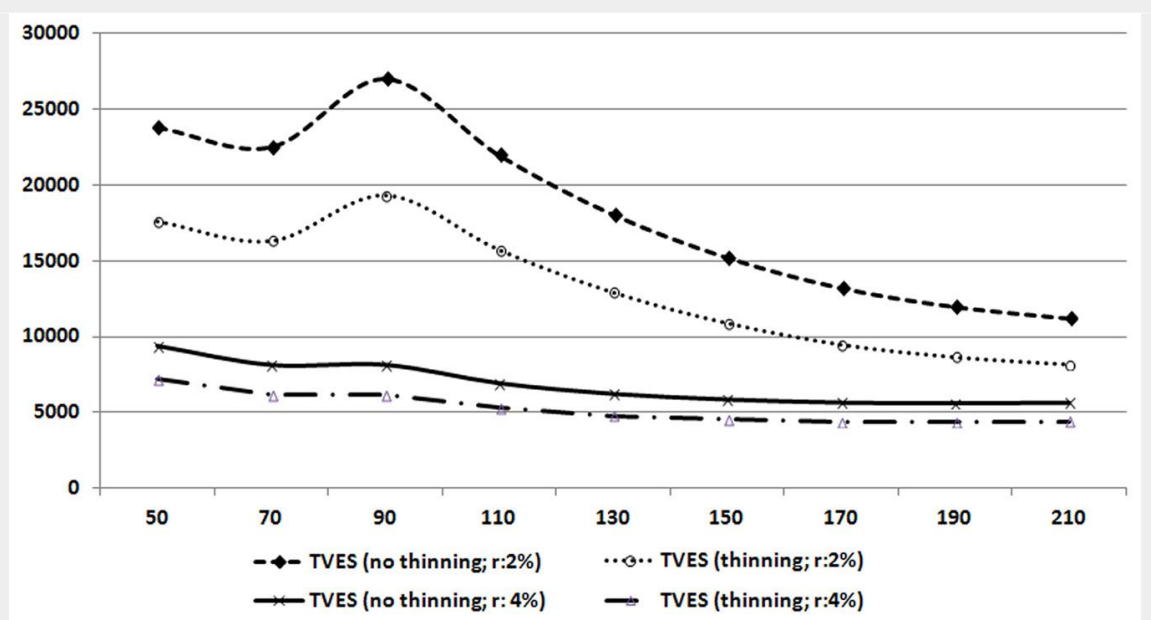

Fig. 5 - Variation in the economic value of ecosystem services ( $€$, y-axis) with respect to rotation period (years, $x$-axis), thinning intervention and discount rate. mum rotation period for silver fir. In order to analyze a greater interval, 50 years was chosen as a valid lower limit for mature stands.

The PSRP is equal to 88 years and decreases to the minimum allowable value (50 years) as the discount rate increases from $3 \%$ to $4 \%$. In the case of thinning, the trend is similar but with a lower rotation age (81 years). In general, increasing the discount rate not only decreases the VPS but also shortens the PSRP.

As explained above, RSRP is strictly dependent on the annual increase in volume. This means that the minimum rotation period is always the best option when trying to maximize regulating services.

The VSS improves for SSRP of 54 to 110 years, in both the absence and presence of thinning. The SSRP (110 years) maximizes VSS when the discount rate is equal to or greater than $2 \%$. Maximum VCS are associated with a CSRP equal to the highest admissible age, as discussed earlier.

Due to the great importance of the VPS of the examined forest, the SRP tends to correspond to the PSRP for the whole range of sensitivity analyses. The only exception is in the absence of thinning and for a 3\% discount rate, which yield an intermediate value of 51 years that is probably influenced by the economic importance of carbon sequestration.

Once the total value has been optimized, decision makers have a guideline for analyzing different types of forest management. ES trade-off analysis provides another useful output. In other words, the variation (reduction) in value of a specific ecosystem service resulting from the maximization of other values should be highlighted, as indicated in Fig. 6.

The greatest contrast among VPS, VSS and VCS is found in the case of VPS maximization. Production of traditional assortments is often in contrast with tourismrecreational functions and with preserving biodiversity. A similar trend is defined in 
Tab. 2 - Optimal rotation periods and values of forest related to presence/absence of thinning and discount rate (r).

\begin{tabular}{|c|c|c|c|c|c|c|c|c|c|c|c|}
\hline \multicolumn{6}{|c|}{ Presence of thinning } & \multicolumn{6}{|c|}{ Absence of thinning } \\
\hline$r$ & $1 \%$ & $2 \%$ & $3 \%$ & $4 \%$ & $5 \%$ & $r$ & $1 \%$ & $2 \%$ & $3 \%$ & $4 \%$ & $5 \%$ \\
\hline PSRP & 88 & 88 & 88 & 50 & 50 & PSRP & 81 & 81 & 81 & 50 & 50 \\
\hline VPS & 57899 & 17198 & 6491 & 3480 & 2028 & VPS & 39981 & 11645 & 4111 & 1597 & 798 \\
\hline VRS & 14928 & 8009 & 5661 & 4685 & 3821 & VRS & 13176 & 7220 & 5201 & 4425 & 3648 \\
\hline VSS & 3643 & 1851 & 1257 & 997 & 815 & VSS & 3665 & 1851 & 1252 & 997 & 815 \\
\hline VCS & 1328 & 578 & 334 & 178 & 131 & VCS & 1309 & 574 & 334 & 182 & 134 \\
\hline VES & 77797 & 27635 & 13744 & 9340 & 6796 & VES & 58131 & 21289 & 10898 & 7201 & 5395 \\
\hline RSRP & 50 & 50 & 50 & 50 & 50 & RSRP & 50 & 50 & 50 & 50 & 50 \\
\hline VPS & 33050 & 12584 & 6285 & 3480 & 2028 & VPS & 19706 & 7032 & 3228 & 1597 & 798 \\
\hline VRS & 17390 & 8940 & 6110 & 4685 & 3821 & VRS & 15716 & 8216 & 5699 & 4425 & 3648 \\
\hline VSS & 3719 & 1904 & 1299 & 997 & 815 & VSS & 3719 & 1904 & 1299 & 997 & 815 \\
\hline VCS & 903 & 419 & 258 & 178 & 131 & VCS & 927 & 429 & 263 & 182 & 134 \\
\hline VES & 55062 & 23847 & 13953 & 9340 & 6796 & VES & 40068 & 17581 & 10489 & 7201 & 5395 \\
\hline SSRP & 54 & 110 & 110 & 110 & 110 & SSRP & 54 & 110 & 110 & 110 & 110 \\
\hline VPS & 34703 & 11762 & 3708 & 1248 & 431 & VPS & 20880 & 6379 & 1317 & -60 & -393 \\
\hline VRS & 17101 & 7651 & 5524 & 4395 & 3671 & VRS & 15306 & 6701 & 4990 & 4066 & 3458 \\
\hline VSS & 3775 & 1949 & 1345 & 1041 & 857 & VSS & 3775 & 1949 & 1345 & 1041 & 857 \\
\hline VCS & 958 & 631 & 355 & 227 & 157 & VCS & 985 & 653 & 366 & 233 & 160 \\
\hline VES & 56537 & 21994 & 10932 & 6910 & 5115 & VES & 40945 & 15682 & 8018 & 5279 & 4082 \\
\hline CSRP & 300 & 300 & 300 & 300 & 300 & CSRP & 300 & 300 & 300 & 300 & 300 \\
\hline VPS & 5916 & 293 & 293 & 1 & 0 & VPS & 1496 & -1463 & -1221 & -921 & -692 \\
\hline VRS & 10075 & 6900 & 6900 & 4344 & 3656 & VRS & 8351 & 5853 & 4812 & 4016 & 3443 \\
\hline VSS & 3512 & 1832 & 1832 & 978 & 803 & VSS & 3512 & 1749 & 1266 & 978 & 803 \\
\hline VCS & 1948 & 726 & 726 & 233 & 159 & VCS & 1999 & 653 & 391 & 240 & 162 \\
\hline VES & 21451 & 9751 & 9751 & 5557 & 4618 & VES & 15358 & 6783 & 5247 & 4313 & 3717 \\
\hline SRP & 88 & 88 & 51 & 50 & 50 & SRP & 81 & 81 & 81 & 50 & 50 \\
\hline VPS & 57899 & 17198 & 6299 & 3480 & 2028 & VPS & 39981 & 11645 & 4111 & 1597 & 798 \\
\hline VRS & 14928 & 8009 & 6094 & 4685 & 3821 & VRS & 13176 & 7220 & 5201 & 4425 & 3648 \\
\hline VSS & 3643 & 1851 & 1304 & 997 & 815 & VSS & 3665 & 1851 & 1252 & 997 & 815 \\
\hline VCS & 1328 & 578 & 261 & 178 & 131 & VCS & 1309 & 574 & 334 & 182 & 134 \\
\hline VES & 77797 & 27635 & 13958 & 9340 & 6796 & VES & 58131 & 21289 & 10898 & 7201 & 5395 \\
\hline
\end{tabular}

maximizing the VES. The VRS decreases substantially when the VCS is improved (33\% reduction). An interesting output is the low variability of the VPS, VRS, VCS and VES in the case of VSS maximization. In the case of this study it means that optimization of biodiversity shows a little conflict with other values.

\section{Comparison of TOOFES with other tools for ES evaluation}

A number of models and DSS for ES evaluation are described in the literature (Bagstad et al. 2013). In order to facilitate comparison between TOOFES and other available tools, the evaluative criteria proposed by Bagstad et al. (2013) are briefly discussed. The criteria are: (i) quantification of output, nonmonetary and cultural perspectives, uncertainty evaluation; (ii) capacity of independent applications by users; (iii) level of development and documentation; (iv) scalability; (v) time requirements; (vi) generalizability; and (vii) affordability, insights, integration with existing environmental assessment.

(i) Quantification of output, nonmonetary and cultural perspectives, uncertainty evaluation. Outputs are calculated in quantitative terms. The monetary value of ES is the main output. Specific data (e.g., total cubic meters of assortments, total stored carbon, average relative richness and number of visits) can be se- lected by means of "summarize operation" on Processing sheet. Uncertainty can be analyzed using varying inputs (sensitivity analysis).

(ii) Capacity of independent applications. The spreadsheet structure and opensource implementation facilitate the independent use of the model. TOOFES will be available on request by e-mailing the author.

(iii) Level of development and documentation. TOOFES is fully documented for the analyzed ES. Additional ES functions can be included and documented in future versions.

(iv) Scalability. Model outputs can be defined for different forest areas according to the size of the study area and available input data. TOOFES is designed for application at the stand scale, a scale considered suitable for decision support in operational forest management (Lang- ner et al. 2017). The structure of the model is such that analyses can be undertaken at different scales, including large scales. This option is possible through the transformation of large-scale input data such as digital raster maps (forest information, roads, digital terrain models, etc.) into ASCII data. Said transformation can be completed in any classic Geographic Information System and allows this data to be input into a spreadsheet, thereby facilitating the optimization procedure.

(v) Time requirements. It does not take long to run the model once input data are available. In general, a few runs are necessary for the analysis of provisioning and regulating services. It can take much longer if field surveys are required to implement input data (usually for cultural services if the Benefit Transfer approach cannot be applied). The calculations in

\begin{tabular}{|c|c|c|c|c|c|c|}
\hline & MAX TVPS & MAX TVRS & MAX TVSS & MAX TVCS & MAX TVES & \\
\hline MAX TVPS & - & $18.5 \%$ & $67.1 \%$ & $117.1 \%$ & $0.3 \%$ & uction $<10$ \\
\hline MAX TVRS & $6.9 \%$ & - & $8.3 \%$ & $60 \quad 19.5 \%$ & $6.2 \%$ & $10.1 \%<$ reduction $<50 \%$ \\
\hline MAX TVSS & $4.8 \%$ & $3.3 \%$ & - & $6.7 \%$ & $4.5 \%$ & reduction $>50.1 \%$ \\
\hline MAX TVCS & $20.8 \%$ & $33.1 \%$ & $13.6 \%$ & - & $22.7 \%$ & \\
\hline MAX TVES & $0.2 \%$ & $9.5 \%$ & $25.4 \%$ & $6 \quad 52.4 \%$ & - & \\
\hline
\end{tabular}

Fig. 6 - Trade-off analysis among ES functions. Reduction in the value of a specific function (columns) when the value of another function is maximized (rows). 
the optimization procedure take only a few minutes (for example, the SRP can be determined in about 2 minutes when using a calculator with a $3 \mathrm{GHz}$-processor and $8 \mathrm{~GB}$ of RAM). The computational time and CPU requirements increase for large-scale analyses.

(vi) Generalizability. The high degree of customizability of input data facilitates the use of this tool.

(vii) Affordability, insights, integration with existing environmental assessment. Model results can fit with established forest management and planning processes, taking into account normative prescriptions. For example, the optimization procedure can be carried out setting constraints such as the minimum rotation age admissible by local laws or additional quantitative parameters (minimum production of wood assortments or stored carbon, etc.). Forest management and silvicultural treatments can be calibrated in the DSS according to local peculiarities and practices. Thanks to its user-friendly output and graphical interface, TOOFES can be readily applied by decision makers.

\section{Final remarks}

This study implemented a Decision Support System (DSS) named TOOFES for quantifying economic value and trade-offs in forest ecosystem services (ES). The DSS enables the dynamic analysis and planning of forest functions throughout the forest life cycle. TOOFES is based on an opensource spreadsheet, allowing its ready and widespread application. The flexible structure allows for its application in different study areas and locations, and facilitates updating of ES and results. In this case study, TOOFES was applied to the analysis of homogenous stands at a small scale. The structure of the model also allows its application to large-scale evaluations, as already discussed. Other GIS-based models for quantifying ES (e.g., ARIES: http://aries.inte gratedmodelling.org/; or InVEST: http://ww w.naturalcapitalproject.org/invest/) could reduce the time required to analyse vaster, more complex areas. However, unlike other available tools, the structure of TOOFES is such that it can be used for more than just simple ES trade-off analysis. It allows the optimization of specific objective functions (e.g., maximizing the value of forest ES) by setting constraint parameters.

As in other modeling procedures, missing data in the analyzed area can create some problems in TOOFES. More general data can be used to substitute the missing one; however, the main problem lies in downscaling and the maximum standard error admitted in model outputs. For example, due to the scarcity of yield tables (norms) for uneven-aged stands at the national level, this first version of the model could be applied to even-aged forests, with more research needed for the analysis of un- even-aged stands. In TOOFES, monetary evaluations can consider the Net Present Value as well as the annual flow of ES, as in the majority of studies. However, output data focus on the capitalized value of the forest. When implementing Payments for Ecosystem Services (PES) schemes, in order to follow the dictates of economic valuation and appraisal in forestry, it seems more appropriate to determine the capitalized value rather than the NPV. Additional economic outputs may be investigated in future works. Tab. S1 (Supplementary material) reports other available outputs.

The main strength of the model is its ability to analyze complex systems. TOOFES improves upon the "static" evaluation presented in most scientific papers and DSS by taking into account the temporal variability of forest characteristics (e.g., volume and forest landscape). This can be useful in achieving the objective of sustainability in forest management. For example, in the framework of the 2030 Agenda for Sustainable Development, the identification of strategies for sustainable forest management (indicator 15.2.1) could facilitate the analysis of Sustainable Development Goal 15: "Protect, restore and promote sustainable use of terrestrial ecosystems, sustainably manage forests, combat desertification, and halt and reverse land degradation and halt biodiversity loss".

Future analyses can introduce mixedmethod valuation. Monetary calculations can be suitably integrated/substituted with non-monetary trade-offs based on multicriteria analysis and a combination of biophysical variables. This could lead to the development of alternative approaches to classical environmental economics. The lack of rivalry and excludability in public goods and services may lead to a difficult and controversial monetization of ES (Farley \& Costanza 2010). This approach can possibly contribute to regional and national policies in that it allows the simultaneous quantification and planning of different $\mathrm{ES}$ in individual forested areas. Best management strategies can be developed taking into account the priorities and perceptions of different local stakeholders. Minimum levels of supplied ES can also be established and verified through scenario analysis. Guidelines for the emerging sector of Payment for Ecosystem Services could be established in line with the updated national normative framework (see Collegato Ambientale - Gazzetta Ufficiale 2016). In particular, the model could facilitate and improve methods for national ES accounting. Additional scenario analyses that take into account risk parameters as well as anthropogenic and natural damage assessment should be examined.

In conclusion, the proposed DSS with the suggested improvements could be an effective tool for the dynamic analysis and planning of forest ES.

\section{References}

Almansa C, Martinez-Paz JM (2011). What weight should be assigned to future environmental impacts? A probabilistic cost benefit analysis using recent advances on discounting. Science of the Total Environment 409 (7): 1305-1314. doi: 10.1016/j.scitotenv.2010.12.004

Armbrecht J (2014). Use value of cultural experiences: a comparison of contingent valuation and travel cost. Tourism Management 42: 141148. - doi: 10.1016/j.tourman.2013.11.010

Baerenklau KA, Gonzàlez-Cabàn A, Paez C, Chavez $E$ (2010). Spatial allocation of forest recreation value. Journal of Forest Economics 16: 113126. - doi: 10.1016/j.jfe.2009.09.002

Bagstad KJ, Semmens DJ, Waage S, Winthrop R (2013). A comparative assessment of decisionsupport tools for ecosystem services quantification and valuation. Ecosystem Services 5: 2739. - doi: 10.1016/j.ecoser.2013.07.004

Bartkowski B, Lienhoop N, Hansjürgens B (2015). Capturing the complexity of biodiversity: a critical review of economic valuation studies of biological diversity. Ecological Economics 113: 1-14. - doi: 10.1016/j.ecolecon.2015.02.023

Bottalico F, Pesola L, Vizzarri M, Antonello L, Barbati A, Chirici G, Corona P, Cullotta S, Garfì V, Giannico V, Lafortezza R, Lombardi F, Marchetti M, Nocentini S, Riccioli F, Travaglini D, Sallustio $L$ (2016). Modeling the influence of alternative forest management scenarios on wood production and carbon storage: A case study in the Mediterranean region. Environmental Research 144: 72-87. - doi: 10.1016/j.env res.2015.10.025

Brander LM, Koetse MJ (2011). The value of urban open space: meta-analyses of contingent valuation and hedonic pricing results. Journal of Environmental Management 92: 2763-2773. doi: 10.1016/j.jenvman.2011.06.019

Brazee RJ (2001). The Faustmann formula: fundamental to forest economics 150 years after publication. Forest Science 47: 441-442. [online] URL: http://search.proquest.com/openview/64 47c8887525b3f28c5b76207a648dde/1

CMCC (2014). The carbon market. International Climate Policy and Carbon Markets 32: 11.

Costanza R, D’Arge R, De Groot R, Farberk S, Grasso M, Hannon B, Limburg K, Naeem S, O’Neill RV, Paruelo J, Raskin RG, Suttonkk P, Van Den Belt M (1997). The value of the world's ecosystem services and natural capital. Nature 387: 253-260. - doi: 10.1038/387253ao

Costanza R, De Groot R, Sutton P, Van Der Ploeg S, Anderson SJ, Kubiszewski I, Farber S, Turner RK (2014). Changes in the global value of ecosystem services. Global Environmental Change 26: 152-158. - doi: 10.1016/j.gloenvcha.2014.04.0 02

Czembrowski P, Kronenberg J (2016). Hedonic pricing and different urban green space types and sizes: insights into the discussion on valuing ecosystem services. Landscape and Urban Planning 146: 11-19. - doi: 10.1016/j.landurbplan. 2015.10.005

D’Amato D, Rekola M, Li N, Toppinen A (2016). Monetary valuation of forest ecosystem services in China: a literature review and identification of future research needs. Ecological Economics 121: 75-84. - doi: 10.1016/j.ecolecon.2015. 11.009 
De Groot R, Brander L, Van Der Ploeg S, Costanza R, Bernard F, Braat L, Christie M, Crossman N, Ghermandi A, Hein L, Hussain S, Kumar P, McVittie A, Portela R, Rodriguez LC, Ten Brink P, Van Beukering P (2012). Global estimates of the value of ecosystems and their services in monetary units. Ecosystem Services 1: 50-61. - doi: 10.1016/j.ecoser.2012.07.005

Faustmann M (1849). On the determination of the value which forestland and immature stands pose for forestry. Reprinted in Journal of Forest Economics 1: 7-44.

Farley J, Costanza R (2010). Payments for ecosystem services: from local to global. Ecological Economics 69: 2060-2068. - doi: 10.1016/j.eco lecon.2010.06.010

Federici S, Vitullo M, Tulipano S, De Lauretis R, Seufert G (2008). An approach to estimate carbon stocks change in forest carbon pools under the UNFCCC: the Italian case. iForest 1: 86-95. doi: 10.3832/iforo457-0010086

Gazzetta Ufficiale (2016). Law 28 December 2015, n. 221 "Disposizioni in materia ambientale per promuovere misure di green economy e per il contenimento dell'uso eccessivo di risorse naturali" [Environmental provisions for promote green economy measures and for the containment of excessive use of natural resources]. GU General Series no. 13 (18-012016), Web site. [in Italian] [online] URL: http:// www.gazzettaufficiale.it/eli/id/2016/01/18/16Go $0006 / \mathrm{sg}$

Gsottbauer E, Logar I, Van Den Bergh J (2015). Towards a fair, constructive and consistent criticism of all valuation languages: comment on Kallis et al. (2013). Ecological Economics 112: 164-169. - doi: 10.1016/j.ecolecon.2014.12.014 Gürlük S (2006). The estimation of ecosystem services' value in the region of Misi rural development project: results from a contingent valuation survey. Forest Policy and Economics 9: 209-218. - doi: 10.1016/j.forpol.2005.07.007 Häyhä T, Franzese PP (2014). Ecosystem services assessment: a review under an ecological-economic and systems perspective. Ecological Modelling 289: 124-132. - doi: 10.1016/j.ecolmod el.2014.07.002

Häyhä T, Franzese PP, Paletto A, Fath BD (2015). Assessing, valuing, and mapping ecosystem services in Alpine forests. Ecosystem Services 14: 12-23. - doi: 10.1016/j.ecoser.2015.03.001 Hoogstra-Klein MA, Hengeveld GM, Jong $R$ (2017). Analysing scenario approaches for forest management: one decade of experiences in Europe. Forest Policy and Economics 85 (2): 222-234. - doi: 10.1016/j.forpol.2016.10.002

Kallio AMI, Hänninen R, Vainikainen $N$, Luque S (2008). Biodiversity value and the optimal location of forest conservation sites in Southern Finland. Ecological Economics 67: 232-243. - doi: 10.1016/j.ecolecon.2008.05.005

Kandziora M, Burkhard B, Müller F (2013). Interactions of ecosystem properties, ecosystem integrity and ecosystem service indicators - A theoretical matrix exercise. Ecological Indicators 28: 54-78. - doi: 10.1016/j.ecolind.2012.09. 006

Kortsch T, Hildebrand J, Schweizer-Ries P (2015). Acceptance of biomass plants - Results of a longitudinal study in the bioenergy-region Altmark. Renewable Energy 83: 690-697. - doi: 10.1016/j.renene.2015.04.059

Kumar M, Kumar P (2008). Valuation of the ecosystem services: a psycho-cultural perspective. Ecological Economics 64: 808-819. - doi: 10.1016/j.ecolecon.2007.05.008

ISAFA (1970). Tavole stereometriche ed alsometriche costruite per boschi italiani [Yield tables for Italian forests]. Web site. [in Italian] [online] URL: http://mpf.entecra.it/sites/default/files/pu b_interne/

Langner A, Irauschek F, Perez S, Pardos M, Zlatanov T, Nordström EM, Lexer MJ (2017). Valuebased ecosystem service trade-offs in multiobjective management in European mountain forests. Ecosystem Services 26: 245-257. - doi: 10.1016/j.ecoser.2017.03.001

Lankia T, Kopperoinen L, Pouta E, Neuvonen M (2015). Valuing recreational ecosystem service flow in Finland. Journal of Outdoor Recreation and Tourism 10: 14-28. - doi: 10.1016/j.jort.2015. 04.006

Lupp G, Konold W, Bastian O (2013). Landscape management and landscape changes towards more naturalness and wilderness: Effects on scenic qualities - The case of the Müritz National Park in Germany. Journal for Nature Conservation 21: 10-21. - doi: 10.1016/j.jnc.2012.08. 003

Maguire KB (2009). Does mode matter? A comparison of telephone, mail, and in-person treatments in contingent valuation surveys. Journal of Environmental Management 90: 3528-3533. doi: 10.1016/j.jenvman.2009.06.005

Mazzaro De Freitas FL, Sparovek G, Mörtberg U, Silveira S, Klug I, Berndes G (2017). Offsetting legal deficits of native vegetation among Brazilian landholders: effects on nature protection and socioeconomic development. Land Use Policy 68: 189-199. - doi: 10.1016/j.landusepol.20 17.07.014

Mohammed AJ, Inoue M (2017). Identifying salient forest SES attributes for sustainability: a multi-country study. Land Use Policy 60: 197205. - doi: 10.1016/j.landusepol.2016.10.039

Ninan KN, Inoue M (2013). Valuing forest ecosystem services: what we know and what we don't. Ecological Economics 93: 137-149. - doi: 10.1016/j.ecolecon.2013.05.005

Norgaard RB (2010). Ecosystem services: from eye-opening metaphor to complexity blinder. Ecological Economics 69: 1219-1227. - doi: 10.1016/j.ecolecon.2009.11.009

Pearce D, Moran D (1994). The economic value of biodiversity. IUCN - The World Conservation Union, Earthscan Publications Ltd, London, pp. 106.

Plumecocq $G$ (2014). The second generation of ecological economics: how far has the apple fallen from the tree? Ecological Economics 107: 457-468. - doi: 10.1016/j.ecolecon.2014.09.020 Ribe RG (2009). In-stand scenic beauty of variable retention harvests and mature forests in the US Pacific Northwest: the effects of basal area, density, retention pattern and down wood. Journal of Environmental Management 91: 245-260. - doi: 10.1016/j.jenvman.2009.08.0 14

Riccioli F, Fratini R, El Asmar JP, El Asmar T (2012). The use of benefit transfer to estimate the recreational and touristic value of two wooded areas in Tuscany. Journal of Service
Science and Management 5: 14-19. - doi: 10.4236 /jssm.2012.51002

Richardson L, Loomis J, Kroeger T, Casey F (2015). The role of benefit transfer in ecosystem service valuation. Ecological Economics 115: 51-58. - doi: 10.1016/j.ecolecon.2014.02.018 Rose SK, Chapman D (2003). Timber harvest adjacency economies, hunting, species protection, and old growth value: seeking the dynamic optimum. Ecological Economics 44: 325344. - doi: 10.1016/S0921-8009(02)00268-9

Sacchelli S, Zambelli P, Zatelli P, Ciolli M (2013). Biomasfor - An open-source holistic model for the assessment of sustainable forest bioenergy. iForest 6: 285-293. - doi: 10.3832/iforo897006

Sacchelli S, Fabbrizzi S (2015). Minimisation of uncertainty in decision-making processes using optimised probabilistic fuzzy cognitive maps: a case study for a rural sector. Socio-Economic Planning Sciences 52: 31-40. - doi: 10.1016/j.seps. 2015.10.002

Secco L, Favero M, Masiero M, Pettenella DM (2017). Failures of political decentralization in promoting network governance in the forest sector: Observations from Italy. Land Use Policy 62: 79-100. - doi: 10.1016/j.landusepol.2016. 11.013

Sherrouse BC, Semmens DJ (2014). Validating a method for transferring social values of ecosystem services between public lands in the Rocky Mountain region. Ecosystem Services 8: 166177. - doi: 10.1016/j.ecoser.2014.03.008

TEEB (2010). The economics of ecosystems and biodiversity: mainstreaming the economics of nature: a synthesis of the approach, conclusions and recommendations of TEEB. Progress Press, Malta, pp. 36.

Ten Brink BJE, Van Vliet AJH, Heunks C, Pearce DW, Howarth A (2000). Technical report on biodiversity in Europe: an integrated economic and environmental assessment. RIVM report 481505019, National Institute of Public Health and the Environment, Bilthoven, The Netherlands, pp. 74. [online] URL: http://www.rivm. nl/bibliotheek/rapporten/481505019.pdf Turner MG (1989). Landscape ecology: the effect of pattern on process. Annual Review of Ecology and Systematics 20: 171-197. - doi: 10.1146/ annurev.es.20.110189.001131

Turner RK, Paavola J, Cooper P, Farber S, Jessamy V, Georgiou S (2003). Valuing nature: lessons learned and future research directions. Ecological Economics 46: 493-510. - doi: 10.1016/ Sog21-8009(03)00189-7

Tuscany Region (2003). Tuscany Regional Forest Law 48/2003. Web site. [online] URL: http://www.regione.toscana.it/-/regolamentod-attuazione-della-legge-forestale-dellatoscana-l-r-39-00-

Uggla Y, Forsberg M, Larsson S (2016). Dissimilar framings of forest biodiversity preservation: Uncertainty and legal ambiguity as contributing factors. Forest Policy and Economics 62: 36-42. - doi: 10.1016/j.forpol.2015.07.007

Venn TJ (2005). Financial and economic performance of long-rotation hardwood plantation investments in Queensland, Australia. Forest Policy and Economics 7: 437-454. - doi: 10.1016/j.forpol.2003.08.003

Wang W, Fu B (2013). Trade-offs between forest 
ecosystem services. Forest Policy and Economics 26: 145-146. - doi: 10.1016/j.forpol.2012.07.014 Wright D, Dey P, Brammer J, Hunt P (2011) Bioenergy decision support systems: worth the effort? In: Proceedings of the "World Renewable Energy Congress". Linköping (Sweden), 8 13 May 2011. Linköping Electronic Conference Proceedings, vol. 1, no. 57, pp. 9-16.

Yoo J, Simonit S, Connors JP, Kinzig AP, Perrings
C (2014). The valuation of off-site ecosystem service flows: Deforestation, erosion and the amenity value of lakes in Prescott, Arizona. Ecological Economics 97: 74-83. - doi: 10.1016/ j.ecolecon.2013.11.001

Xie XF (2009). Solver for nonlinear programming. Web site. [online] URL: http://extensi ons.services.openoffice.org/project/NLPSolver

\section{Supplementary Material}

Tab. S1 - Additional TOOFES economic output (data processed with a rotation period of 100 years, without thinning and discount rate of $2 \%$ ).

Link: Sacchelli_2416@supploo1.pdf 